\title{
MULTIVARIATE ANALYSIS USING GAMMA SPECTROMETRIC AND GEOCHEMICAL DATA IN AREA OF SUGAR CANE PLANTATION IN THE STATE OF PARANÁ/BRAZIL
}

Valter Antonio Becegato ${ }^{1}$; Sideney Becker Onofre ${ }^{2}$, João Batista Pereira Cabral $^{3}$, Olívia Aparecida Rodolfo Figueiredo ${ }^{1}$

(1 - Professor da UDESC/CAV, Cx. P. 281 Lages, SC, cep. 88.520.000. E-mail becegato@cav.udesc.br; a2oaf@cav.udesc.br; 2 - Professor da UNIPAR, Campus Francisco Beltrão-PR, E-mail sideney@unipar.br; 3 - Professor da UFG - Campus de Jataí-GO, E-mail jbcabra12000@yahoo.com.br)

\section{Summary}

Multivariate analysis was used in area of sugar cane plantation in the State of Paraná (Brazil) in order to understand the correlations between $\mathrm{K}, \mathrm{U}$ and $\mathrm{Th}$ radionuclide and geochemical data for soil samples collected at $0-20 \mathrm{~cm}$ and $20-40 \mathrm{~cm}$ depths. To determine the $\mathrm{K}, \mathrm{U}$ and $\mathrm{Th}$ radionuclide concentrations is soils, fertilizers and gypsum, a Syntrex/Geofyzika GS-512 gamma-ray spectrometer with 512 channels was used, with energy ranging from 0.1 to $3 \mathrm{MeV}$. The minimum and maximum concentrations found in soils for $\mathrm{K}, \mathrm{U}$ and Th radionuclide were respectively $31-124 \mathrm{~Bq} \mathrm{Kg}^{-1} ; 0-12.3 \mathrm{~Bq} \mathrm{Kg}^{-1} ; 0-17.1$ $\mathrm{Bq} \mathrm{Kg}^{-1}$. The maximum variation corresponded to uranium (56\%). Geochemical data for clay, organic matter, phosphorous, potassium, calcium, magnesium, copper, zinc, iron, manganese, and $\mathrm{pH}$ at the $0-20 \mathrm{~cm}$ depth were respectively: $12-30 ; 0.4-1.4 ; 1.2-80 ; 6-132 ; 0.5-$ $3.1 ; 0.2-4.1 ; 0.2-14.2 ; 4-155 ; 15.6-16.1$, and $6.7-7.5$. At $20-40 \mathrm{~cm}$ depth: $12-30$; 0.3 - $1.1 ; 1.4-80 ; 7$ - 200; $0.4-2.4 ; 0.1$ - 0.9; 0.2 - 2.8; 0.1 - 12.6; 4.3 - 114; 18.9 - 149, and e $6.5-7.6$. Correlation exists between radionuclide and geochemical data were obtained at both depths.

Key Words: fertilizers, soils, radionuclide, gamma-ray spectrometry

\section{Resumo}

Recebido para publicação em 17 de Março de 2008; 
ANÁLISE MULTIVARIADA COM DADOS GAMAESPECTROMÉTRICOS E GEOQUÍMICOS EM ÁREA CULTIVADA COM CANA-DE-AÇÚCAR NO ESTADO DO PARANÁ/BRAZIL

Utilizou-se análise multivariada objetivando entender as correlações dos radionuclídeos (K, U e Th), com dados geoquímicos em amostras de solos coletados em duas profundidades 0 - 20 cm e 20 - 40 cm em área cultivada com cana-de-açúcar. Para determinação das concentrações dos radionuclídeos (K, U e Th) nos solos, adubos e gesso, utilizou-se o espectrômetro de raios gama GS-512 fabricação Syntrex/Geofyzika com 512 canais, energias entre 0,1 e $3 \mathrm{MeV}$. Os teores máximo e mínimo encontrados nos solos para os radionuclídeos (K, U e Th) foram respectivamente: 31 - 124; 0 12,3;0 - 17,1 $\mathrm{Bq} \mathrm{Kg}^{-1}$, cuja maior variabilidade foi observada para o urânio com $56 \%$ e os dados geoquímicos para a profundidade $0-20 \mathrm{~cm}$ : Argila, matéria orgânica, fósforo, potássio, cálcio, magnésio, cobre, zinco, ferro mangânes e pH foram respectivamente: $12-30,0,4-1,4,1,2-80,6-132,0,5-3,1,0,2-4,1,0,2-14,2,4$ $-155,15,6-16,1,6,7-7,5$ e para a profundidade de $20-40 \mathrm{~cm}: 12-30,0,3-1,1,1,4-80$, 7 - 200, 0,4 - 2,4, 0,1 - 0,9, 0,2 - 2,8, 0,1 - 12,6, 4,3 - 114, 18,9- 149 e 6,5 - 7,6. Verificouse correlações para as duas profundidades entre os radionuclídeos e os dados geoquímicos.

Palavras-chave: Fertilizantes, solos, radionuclídeos, espectrometria de raios gama.

\section{1 - Introduction}

In the last decade the productivity per area of several crops has increased in Brazil. Sugar cane is an example, with production hitting records year after year, both of sugar to supply internal and external markets and of alcohol as a fuel. The latter started in the 70's and from the 80 's on more than $90 \%$ of the Brazilian vehicles have run on alcohol. The alcohol production is expanding again, contributing to the reduction of pollutants and the greenhouse effect.

The soils in tropical regions are poor in nutrients such as phosphorous and potassium, due to severe leaching. Fertilization is a way to supply nutrients to plants in a commercial scale. Many are the trademarks and formulas found in the market that contain radioactive elements such as $\mathrm{K}, \mathrm{U}$ and $\mathrm{Th}$. These have become a matter of concern and research has been carried out in order to monitor and mitigate the consequences of the use of fertilizers in agriculture.

The radionuclide contents in the fertilizer formulas depend on the source rock and manufacturing. Radioactivity is a natural phenomenon, typical of elements with large and 


\section{GEOAMBIENTE ON-LINE \\ Revista Eletrônica do Curso de Geografia do Campus Jataí - UP \\ www.jatai.ufg.br/geografia \\ | Jataí-GO | N.11 | jul-dez/2008 | ISSN 1679-9860}

unstable nuclei. It is an irreversible mass- and energy-loss process: the atom disintegrates until a stable condition is reached. MARQUES (1988), studying acid, intermediate and basic rocks of the Paraná Basin, found variable uranium and thorium contents, the highest concentrations being found in rhyolite floods. Studies carried out in Australia by DICKSON \& SCOTT (1997) revealed that for the same rock type, U, Th and $\mathrm{K}$ radionuclide concentrations can vary. According to these authors, uranium occurs in the crust at average concentrations of approximately $3 \mathrm{ppm}$ and in two valence forms, $\mathrm{U}^{+4}$ and $\mathrm{U}^{+6}$, being the more reduced found in insoluble minerals. $\mathrm{U}^{+6}$ can form complexes with anions, sulfates and phosphates, forming some soluble species. The average thorium concentration is approximately $12 \mathrm{ppm}$, in two valence forms $\mathrm{Th}^{+3}$ and $\mathrm{Th}^{+4}$ (BOYLE, 1982).

Multivariate analysis is a statistics branch that is based on matrix algebra and aims at the summary, the representation and the interpretation of data from populations in which several variables are evaluated in each experimental unit. The multivariate statistic processes can be classified in two groups: a) one that allows to extract information on the interdependence between variables that characterize each individual, and b) one that allows to obtain information on the dependence between several variables (JOHNSON \& WICHERN, 1990). According to ROMESBURG (1984), cluster analysis is a generic term to designate a series of mathematical methods that can be used to define which elements in a certain cluster are similar, or can be classified.

According to PEREIRA (1995), the principal component analysis is an auxiliary method for cluster and factorial analysis and is a statistical abstraction of the variability inherent to the original data set. Authors such as MEIJER ET AL., (2001), EL-ARABI \& KHALIFA (2002), KUMRU \& BAKAÇ (2003) applied multivariate analysis to environmental studies. The objective of this work is to verify the possible correlations between radionuclide and the geochemical characteristics of an area of sugar can plantation.

\section{2 - Materials and Methods}

The study area is a sugar cane plantation for the production of sugar and alcohol. According to the climatic chart of the State of Paraná (IAPAR, 1978) and adopting Köeppen's classification, it is a mesothermal, humid subtropical climate (Cfa), with hot summer, rains tending to concentrate in the summer months. The annual average precipitation is $1200 \mathrm{~mm}$. The area is set in the third Paranaense high plateau - Bauru Basin (Figure 1), Caiuá Group 
(old Caiuá desert) - Rio Paraná Formation. It is constituted by well-selected sandstones in lenses or strata, with well-rounded grains in the coarser fractions and scarce silt-argillaceous matrix (FERNANDES \& COIMBRA, 1994). According to FERNANDES \& COIMBRA (2000), the depositional context encompasses large-sized eolic constructions and dune complexes of amalgamated winding crests, the former built from fossil dune eolic sandstones and the latter corresponding to subaqueous deposits. The sedimentation environment is characterized by severe, arid to semi-arid climatic conditions.

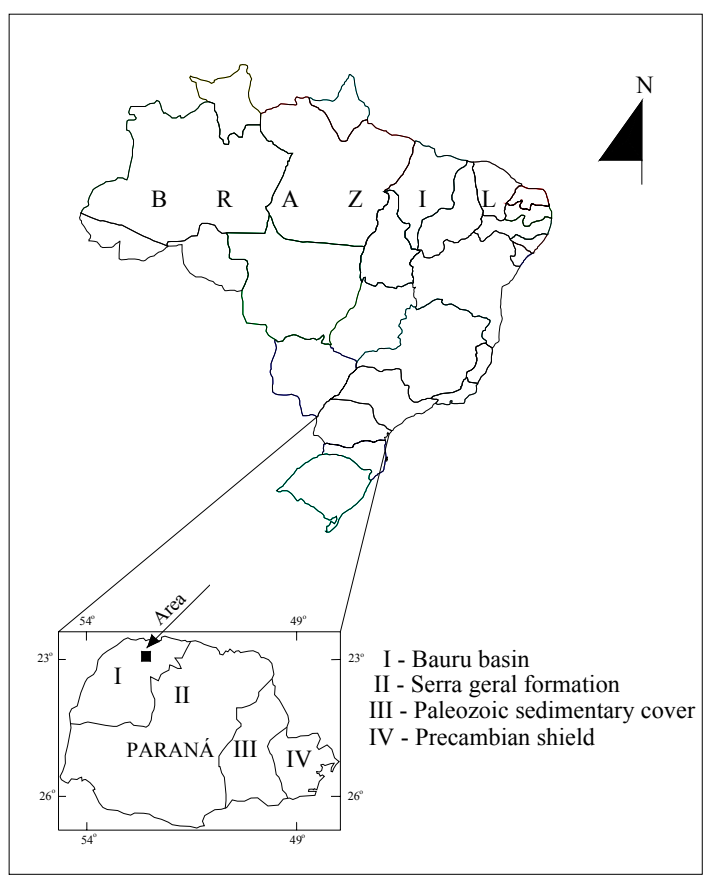

Figure 1 - Location of the study area and the geologic compartments of the State of Paraná.

The sandstone lies discordantly on the Serra Geral Formation. GIMENEZ FILHO et al., (1981) describe the landscape as dominated by ample, short-amplitude hills with straight and continuous convex profiles and extensive planar tops. The ramps are long and slope gently to steeply; the declivity is higher close to the drainage channels.

A net of georeferred points was defined (Figure 2) by GPS. A Syntrex/Geofyzika GS512 gamma-ray spectrometer was used to collect $\mathrm{K}$, eU and eTh gamma radiation data in cps, which are automatically transformed in $\% \mathrm{~K}$ and $\mathrm{ppm}$ eU and $\mathrm{eTh}$. The instrument was calibrated in the Institute of Radioprotection and Dosimetry (IRD) of the National Commission of Nuclear Energy (CNEN) according to BARRETO et al., (1986). These data were collected directly from the chosen points in soil, as well as samples of fertilizer and gypsum used in the sugar cane plantation. The radioactivity was determined by means of 
gamma-ray detection. The main gamma radiation sources are potassium (K), uranium (U) and thorium (Th), which emit gamma quanta in the energy interval above $2615 \mathrm{KeV}$. Potassium spectrometry is based on the detection of the ${ }^{40} \mathrm{~K}$ isotope, whose natural abundance is $0.0012 \%$ of total $\mathrm{K}$. The ${ }^{40} \mathrm{~K}$ isotope emits gamma rays of $1461 \mathrm{KeV}$. It is a direct determination and the results are expressed in $\%$.

The spectrometric determination of uranium in the field was obtained by the detection of $1764 \mathrm{KeV}$ gamma rays coming from ${ }^{214} \mathrm{Bi}$, a product of the ${ }^{238} \mathrm{U}$ disintegration series. This determination is therefore indirect and the data are expressed in ppm. The same applies to thorium, the $2615 \mathrm{KeV}$ gamma rays coming from ${ }^{208} \mathrm{Tl}$, a product of the ${ }^{232} \mathrm{Th}$ disintegration series. The results are also expressed in ppm. The soil samples were collected at $0-20 \mathrm{~cm}$ and $20-40 \mathrm{~cm}$ depths, totaling 158 samples. In the laboratory the following analyses took place: $\mathrm{pH}$, clay, organic matter, phosphorous, potassium, calcium, magnesium, copper, zinc, iron and manganese, following the procedures described in TEDESCO et al., (1995). The data were analyzed by means of descriptive statistics, that is, the calculation of mean, maximum and minimum values, median, skewness, variation coefficient and kurtosis, aiming at the understanding of their behavior in relation to the normal distribution. Multivariate analysis techniques were also applied.

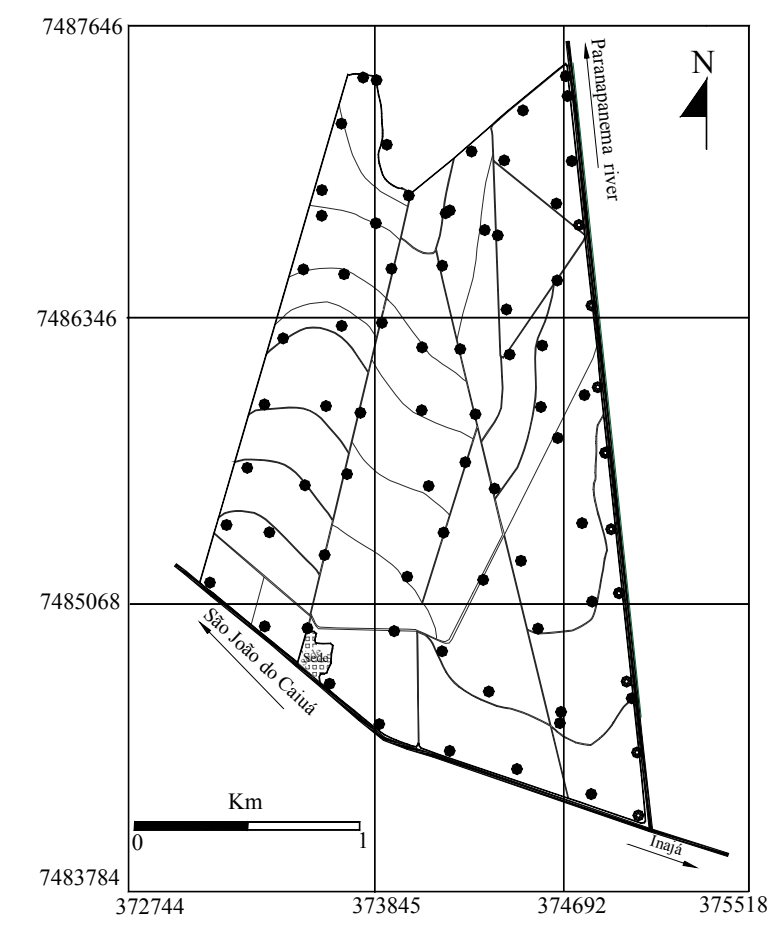

Figure 2 - Net of points analyzed. 


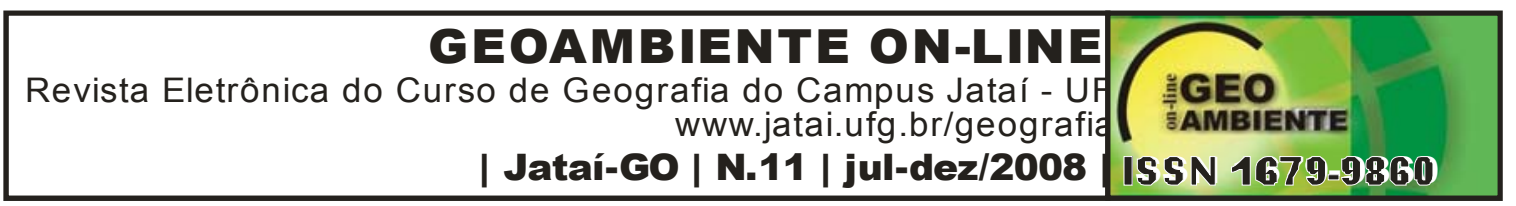

\section{3 - Results and Discussion}

The descriptive statistics is indicated in Table 1, where the skewness and kurtosis coefficients for a normal distribution must be 0 and 3 respectively (SNEDECOR \& COCHRAN, 1967). High positive skewness coefficient values indicate a frequency distribution where the right side of the curve is more elongated in relation to the maximum frequency. In general, the variables that present this behavior tend to a lognormal distribution (OLIVEIRA et al., 1999). Regarding radionuclide, thorium presents a positive skewness distribution, whereas uranium and potassium tend to a distribution very close to normal. Comparing the geochemical values for both depths, clay shows a variability of 19 and $18 \%$ respectively (Table 1$)$.

Table 1. Descriptive statistics for radionuclide and geochemical data of $0-20$ and $20-40 \mathrm{~cm}$ depths.

\section{$0-20 \mathrm{~cm}$ depth}

\begin{tabular}{|c|c|c|c|c|c|c|c|c|c|c|c|c|c|c|}
\hline & ${ }^{40} \mathrm{~K}$ & $\mathrm{U}$ & Th & Clas & .N & $\begin{array}{c}\mathrm{P} \\
---p p\end{array}$ & $\mathrm{~K}$ & $\mathrm{Ca}$ & $\mathrm{Mg}$ & $\mathrm{Cu}$ & $\mathrm{Zn}$ & $\mathrm{Fe}$ & $\mathrm{Mn}$ & $\begin{array}{l}\mathrm{pH} \\
\text { SMP }\end{array}$ \\
\hline Gin & 3 & 0 & 0 & 12 & $0<$ & 1 & 6 & 0 & & & & 4 & & r \\
\hline Iax. & 124 & 12 & 17.1 & 30 & 1.4 & 8 & 132 & & & & & 55 & & 5 \\
\hline les & 7 & & 11.4 & 16.2 & 0.71 & 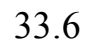 & 35 & & & & & 2 & 4.5 & .2 \\
\hline 1 & 6 & & 1 & 15 & 0 & 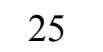 & $2 J$ & & & & & & 59 & 2 \\
\hline 1. & & 3 & 3 & 3.2 & 0.18 & 5 & 27.8 & 0. & 0 & & & 27.7 & 28.6 & 18 \\
\hline c. & & 0. & 0.31 & 0.19 & 0. & 0.7 & 0. & & 0. & & & 0.95 & 0.44 & 02 \\
\hline k. * & & -0 & 1.1 & 1.68 & 1.0 & 0. & 1.84 & 0. & 1.1 & & 4 & 2.57 & 1.04 & -0.3 \\
\hline ur.* & .31 & -0.65 & 0.84 & 3.89 & 1.82 & -0.47 & 3.16 & 0.93 & 1.5 & 10.3 & 22.3 & 7.5 & 1.35 & -0.2 \\
\hline
\end{tabular}

\section{$20-40 \mathrm{~cm}$ depth}

$\begin{array}{lllllllllllllll}\text { Min. } & 31 & 0 & 0 & 12 & 0.3 & 1.4 & 7 & 0.4 & 0.1 & 0.2 & 0.1 & 4.3 & 18.9 & 6.5\end{array}$

$\begin{array}{lllllllllllllll}\text { Max. } & 124 & 12.3 & 17.1 & 30 & 1.1 & 80 & 200 & 2.4 & 0.9 & 2.8 & 12.6 & 114 & 149 & 7.6\end{array}$

$\begin{array}{lllllllllllllll}\text { Mean } & 71 & 5.97 & 11.2 & 16.9 & 0.68 & 30.7 & 35 & 1.2 & 0.3 & 0.81 & 2.1 & 26.8 & 55.6 & 7.1\end{array}$

$\begin{array}{lllllllllllllll}\text { Md. } & 62 & 6.2 & 11.8 & 16 & 0.7 & 22.1 & 26 & 1.2 & 0.3 & 0.6 & 1.2 & 22.4 & 53 & 7.2\end{array}$

$\begin{array}{lllllllllllllll}\text { Sd. } & 19.2 & 3.4 & 3.74 & 3.1 & 0.15 & 23.4 & 29 & 0.5 & 0.17 & 0.5 & 2.5 & 19.2 & 24.5 & 0.22\end{array}$

$\begin{array}{lllllllllllllll}\text { Vc. } & 0.27 & 0.56 & 0.34 & 0.18 & 0.23 & 0.76 & 0.83 & 0.4 & 0.51 & 0.66 & 1.2 & 0.72 & 0.44 & 0.03\end{array}$

$\begin{array}{lllllllllllllll}\text { Sk.* } & 0.35 & -0.22 & 1.1 & 1.55 & 0.28 & 0.98 & 3.2 & 0.4 & 0.93 & 1.7 & 2.6 & 1.9 & 1.5 & -0.5\end{array}$

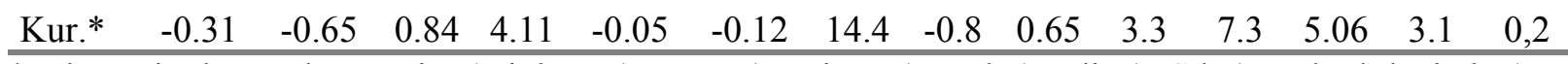

* Dimensionless values. Min. (minimum); Max. (maximum); Md. (median); Sd. (standard deviation); Vc. (variation coefficient); Sk. (skewness); Kur. (kurtosis); O.M (organic matter).

The same applies to organic matter, whose variation coefficients are 25 and $23 \%$, although higher values were expected for the $0-20 \mathrm{~cm}$ depth. These low organic matter 


\section{GEOAMBIENTE ON-LINE \\ Revista Eletrônica do Curso de Geografia do Campus Jataí - UP \\ www.jatai.ufg.br/geografia \\ | Jataí-GO | N.11 | jul-dez/2008 | ISSN 1679-9860}

contents are explained by the type of sugar cane harvest, where burning is adopted to lower the amount of straw and make the harvest easier, increasing efficiency and the mechanical storage (MENDONZA et al., 2000).

Other factors that contribute to the low organic matter content in tropical and subtropical soils are the high temperatures and the rains that promote fast organic matter decomposition by microorganisms, favored by the soil geochemical conditions, notably $\mathrm{pH}$ values in the range of 5.5 to 7.0. Calcium and magnesium contents come from the addition of dolomitic limestone, so that $\mathrm{pH}$ levels are brought to an ideal interval. The soil is chemically poor, of sandy texture, and basically constituted by quartz and average clay content of $16 \%$ (Table 1) at both depths. Phosphorous and potassium are added as fertilizers; copper, zinc, iron and manganese are not of anthropic origin, once the formulas are constituted by NPK. Even so, differences in the contents of these elements are observed at both depths, the origin being attributed to weathered mafic basic rocks covered by younger sandstones (FERNANDES \& COIMBRA, 2000), originating reworked soils involving both rock types (EMBRAPA, 1984).

Significant correlations are observed between uranium and thorium, clay and thorium, and clay and uranium for the $0-20 \mathrm{~cm}$ depth (Table 2). For the $20-40 \mathrm{~cm}$ depth the most significant correlation occurs between uranium and thorium (Table 3). KUMRU \& BAKAÇ (2003) did not establish significant correlations between Fe, K, Mn, U and Th for soil samples. On the other hand, NAVAS et al., (2002) obtained significant correlation values between $\mathrm{K}$ and $\mathrm{U}$, and $\mathrm{Th}$ and $\mathrm{Ra}$.

Table 2. Correlation matrix for the $0-20 \mathrm{~cm}$ depth soil samples.

\begin{tabular}{ccccccccccccccc}
\hline & & & & & & & & & & & & & \\
& ${ }^{39} \mathrm{~K}$ & $\mathrm{U}$ & $\mathrm{Th}$ & Clay & $\mathrm{pH}$ & $\mathrm{P}$ & ${ }^{40} \mathrm{~K}$ & $\mathrm{O} . \mathrm{M}$ & $\mathrm{Ca}$ & $\mathrm{Mg}$ & $\mathrm{Cu}$ & $\mathrm{Zn}$ & $\mathrm{Fe}$ & $\mathrm{Mn}$ \\
\hline${ }^{39} \mathrm{~K}$ & 1 & & & & & & & & & & & & \\
$\mathrm{U}$ & 0.08 & 1 & & & & & & & & & & & \\
$\mathrm{Th}$ & 0.16 & $\mathbf{0 . 8 8}^{\mathbf{a}}$ & 1 & & & & & & & & & & \\
$\mathrm{Clay}$ & 0.11 & $\mathbf{0 . 9 0}$ & $\mathbf{0 . 8 4}$ & 1 & & & & & & & & & \\
$\mathrm{PH}$ & -0.09 & -0.07 & -0.10 & -0.07 & 1 & & & & & & & & \\
$\mathrm{P}$ & 0.04 & -0.02 & 0.01 & -0.03 & 0.01 & 1 & & & & & & & \\
${ }^{40} \mathrm{~K}$ & 0.02 & 0.25 & 0.24 & 0.24 & 0.16 & -0.09 & 1 & & & & & & \\
$\mathrm{O} . \mathrm{M}$ & 0.01 & -0.06 & -0.01 & -0.04 & 0.01 & 0.02 & -0.26 & 1 & & & & & \\
$\mathrm{Ca}$ & -0.01 & 0.00 & 0.01 & 0.02 & -0.09 & 0.04 & -0.08 & -0.04 & 1 & & & & \\
$\mathrm{Mg}$ & -0.07 & -0.18 & -0.16 & -0.27 & 0.07 & 0.11 & 0.06 & -0.08 & -0.01 & 1 & & & \\
$\mathrm{Cu}$ & -0.04 & 0.04 & -0.01 & 0.02 & 0.06 & 0.28 & 0.00 & 0.01 & -0.07 & 0.16 & 1 & & \\
$\mathrm{Zn}$ & -0.03 & -0.06 & 0.00 & -0.04 & -0.07 & 0.01 & -0.12 & -0.03 & -0.11 & 0.01 & -0.01 & 1 & & \\
\hline
\end{tabular}




\begin{tabular}{|c|c|c|c|c|c|c|c|c|c|c|c|c|c|c|}
\hline $\mathrm{Fe}$ & -0.01 & -0.11 & -0.03 & -0.12 & 0.16 & 0.28 & 0.16 & 0.02 & -0.14 & 0.21 & 0.12 & 0.10 & 1 & \\
\hline $\mathrm{MnO}$ & -0.01 & -0.07 & -0.05 & -0.12 & 0.15 & 0.20 & 0.10 & 0.05 & -0.10 & 0.10 & 0.07 & 0.32 & 0.28 & 1 \\
\hline
\end{tabular}

Table 3. Correlation matrix for the $20-40 \mathrm{~cm}$ depth soil samples.

\begin{tabular}{ccccccccccccccc}
\hline & ${ }^{39} \mathrm{~K}$ & $\mathrm{U}$ & $\mathrm{Th}$ & Clay & $\mathrm{pH}$ & $\mathrm{P}$ & ${ }^{40} \mathrm{~K}$ & $\mathrm{O} . \mathrm{M}$ & $\mathrm{Ca}$ & $\mathrm{Mg}$ & $\mathrm{Cu}$ & $\mathrm{Zn}$ & $\mathrm{Fe}$ & $\mathrm{Mn}$ \\
\hline${ }^{39} \mathrm{~K}$ & 1 & & & & & & & & & & & & \\
$\mathrm{U}$ & 0.15 & 1 & & & & & & & & & & & \\
$\mathrm{Th}$ & 0.03 & $\mathbf{0 . 7 5}$ & 1 & & & & & & & & & & \\
$\mathrm{Clay}$ & -0.07 & 0.04 & -0.07 & 1 & & & & & & & & & \\
$\mathrm{PH}$ & -0.08 & -0.04 & 0.01 & -0.04 & 1 & & & & & & & & \\
$\mathrm{P}$ & -0.13 & -0.08 & 0.04 & 0.01 & 0.10 & 1 & & & & & & & \\
${ }^{40} \mathrm{~K}$ & 0.20 & 0.01 & -0.01 & 0.02 & 0.09 & -0.01 & 1 & & & & & & \\
$\mathrm{O} . \mathrm{M}$ & -0.02 & 0.11 & 0.18 & 0.19 & 0.02 & 0.13 & 0.0 & 1 & & & & & \\
$\mathrm{Ca}$ & -0.05 & -0.09 & -0.06 & 0.10 & -0.01 & 0.06 & 0.04 & -0.05 & 1 & & & & \\
$\mathrm{Mg}$ & 0.05 & -0.03 & -0.03 & -0.02 & -0.09 & -0.05 & -0.20 & -0.14 & -0.11 & 1 & & & \\
$\mathrm{Cu}$ & -0.14 & 0.08 & 0.17 & -0.05 & 0.09 & 0.06 & 0.00 & -0.06 & -0.07 & -0.05 & 1 & & \\
$\mathrm{Zn}$ & -0.09 & -0.08 & -0.02 & -0.03 & 0.14 & 0.36 & -0.19 & -0.02 & 0.00 & 0.18 & 0.01 & 1 & \\
$\mathrm{Fe}$ & 0.09 & 0.24 & 0.25 & -0.07 & 0.12 & 0.06 & 0.08 & 0.18 & -0.04 & 0.16 & 0.03 & 0.04 & 1 \\
$\mathrm{MnO}$ & 0.09 & 0.14 & -0.02 & 0.20 & 0.16 & 0.17 & -0.03 & 0.01 & 0.18 & 0.21 & 0.22 & 0.09 & 0.20 & 1 \\
\hline
\end{tabular}

${ }^{a}$ Significant level at 0.05 .

The principal component coefficients are shown in Tables 4 and 5. The technique is used to reduce the number of variables in a set of data by linear combinations so that these combinations explain the major variability of the data in a new set of variables, named components, which do not correlate with each other (JOHNSON \& WICHERN, 1990).

Table 4. Principal component matrix for the $0-20 \mathrm{~cm}$ depth.

\begin{tabular}{cccccc} 
Factor & Factor1 & Factor2 & Factor3 & Factor4 & Factor5 \\
\hline${ }^{39} \mathrm{~K}$ & -0.19 & -0.02 & 0.19 & -0.07 & -0.22 \\
$\mathrm{U}$ & $\mathbf{- 0 . 9 4}$ & 0.15 & 0.04 & -0.03 & 0.04 \\
$\mathrm{Th}$ & $\mathbf{- 0 . 9 1}$ & 0.18 & 0.12 & 0.00 & 0.00 \\
\hline
\end{tabular}




\begin{tabular}{cccccc}
\hline Clay & $\mathbf{- 0 . 9 4}$ & 0.10 & 0.07 & -0.01 & 0.05 \\
$\mathrm{pH}$ & 0.14 & 0.34 & -0.40 & 0.05 & 0.51 \\
$\mathrm{P}$ & 0.10 & 0.49 & 0.37 & -0.49 & -0.11 \\
${ }^{40} \mathrm{~K}$ & -0.32 & 0.37 & $\mathbf{- 0 . 6 4}$ & 0.11 & -0.08 \\
Organic matter & 0.09 & -0.08 & 0.52 & -0.03 & $\mathbf{0 . 6 5}$ \\
$\mathrm{Ca}$ & -0.04 & -0.30 & 0.04 & -0.41 & -0.38 \\
$\mathrm{Mg}$ & 0.33 & 0.35 & -0.23 & -0.26 & -0.24 \\
$\mathrm{Cu}$ & 0.05 & 0.43 & 0.12 & -0.50 & 0.11 \\
$\mathrm{Zn}$ & 0.11 & -0.26 & 0.43 & $\mathbf{0 . 5 9}$ & -0.33 \\
$\mathrm{Fe}$ & 0.20 & $\mathbf{- 0 . 6 7}$ & 0.00 & -0.01 & 0.02 \\
$\mathrm{Mn}$ & 0.19 & $\mathbf{- 0 . 6 0}$ & 0.22 & 0.36 & -0.09 \\
\hline
\end{tabular}

Table 5. Principal component matrix for the $20-40 \mathrm{~cm}$ depth.

\begin{tabular}{cccccc}
\hline Factor & Factor1 & Factor2 & Factor3 & Factor4 & Factor5 \\
\hline${ }^{39} \mathrm{~K}$ & 0.18 & 0.33 & -0.12 & $\mathbf{0 . 5 7}$ & -0.19 \\
$\mathrm{U}$ & $\mathbf{0 . 8 4}$ & 0.22 & -0.07 & -0.03 & 0.13 \\
$\mathrm{Th}$ & $\mathbf{0 . 8 4}$ & 0.14 & -0.07 & -0.28 & 0.08 \\
$\mathrm{Clay}$ & 0.02 & -0.12 & 0.44 & 0.31 & $\mathbf{0 . 5 6}$ \\
$\mathrm{pH}$ & 0.11 & -0.36 & 0.25 & -0.06 & -0.52 \\
$\mathrm{P}$ & 0.08 & $\mathbf{- 0 . 6 2}$ & 0.23 & -0.20 & -0.01 \\
${ }^{40} \mathrm{~K}$ & 0.06 & 0.31 & 0.46 & -0.27 & -0.49 \\
Organic matter & 0.33 & -0.05 & 0.41 & -0.12 & 0.40 \\
$\mathrm{Ca}$ & -0.14 & -0.16 & 0.40 & 0.28 & 0.10 \\
$\mathrm{Mg}$ & 0.02 & -0.29 & $\mathbf{- 0 . 6 7}$ & 0.40 & 0.14 \\
$\mathrm{Cu}$ & 0.26 & -0.23 & -0.02 & -0.24 & -0.34 \\
$\mathrm{Zn}$ & -0.02 & $\mathbf{- 0 . 6 7}$ & -0.21 & -0.15 & 0.00 \\
$\mathrm{Fe}$ & 0.55 & -0.17 & -0.07 & -0.24 & -0.15 \\
$\mathrm{Mn}$ & 0.28 & -0.53 & 0.09 & 0.55 & -0.03 \\
\hline
\end{tabular}

The factorial analysis data by principal components and varimax rotation are presented in tables 6 and 7. The aim is to find the axes with the least high weights and as many weights close to zero as possible. The factorial analysis is a multivariate analysis technique that aims at explaining the correlation within a data set with a great number of variables in terms of a new set with a few random variables called factors (CLEMENTE, 1990).

Table 6 . The factorial analysis data by varimax rotation at $0-20 \mathrm{~cm}$ depth. 


\begin{tabular}{|c|c|c|c|c|c|}
\hline \multicolumn{4}{|c|}{$\begin{array}{r}\text { GEOAMB IENTE ON-LINE } \\
\text { Revista Eletrônica do Curso de Geografia do Campus Jataí - Uf } \\
\text { www.jatai.ufg.br/geografie } \\
\text { | Jataí-Go | N.11 | jul-dez/2008 }\end{array}$} & \multicolumn{2}{|c|}{ ISSN $1679-9860$} \\
\hline${ }^{39} \mathrm{~K}$ & 0.17 & -0.05 & 0.00 & 0.04 & 0.31 \\
\hline $\mathrm{U}$ & 0.95 & 0.06 & 0.06 & 0.00 & 0.05 \\
\hline Th & 0.93 & -0.03 & 0.03 & 0.14 & 0.10 \\
\hline Clay & 0.94 & 0.07 & 0.01 & -0.04 & 0.06 \\
\hline $\mathrm{pH}$ & -0.05 & 0.06 & 0.06 & 0.13 & -0.72 \\
\hline $\mathrm{P}$ & 0.00 & -0.12 & -0.09 & 0.77 & 0.19 \\
\hline${ }^{40} \mathrm{~K}$ & 0.32 & 0.09 & 0.65 & 0.00 & -0.38 \\
\hline Organic matter & 0.00 & 0.08 & -0.81 & 0.09 & -0.19 \\
\hline $\mathrm{Ca}$ & -0.06 & 0.33 & 0.12 & 0.08 & 0.52 \\
\hline $\mathrm{Mg}$ & -0.30 & -0.02 & -0.38 & 0.42 & -0.04 \\
\hline $\mathrm{Cu}$ & 0.05 & 0.09 & -0.06 & 0.67 & -0.06 \\
\hline $\mathrm{Zn}$ & -0.03 & -0.82 & -0.03 & -0.12 & 0.19 \\
\hline $\mathrm{Fe}$ & -0.05 & -0.36 & -0.14 & 0.50 & -0.30 \\
\hline Mn & -0.04 & -0.71 & -0.05 & 0.24 & -0.17 \\
\hline Eigenvalue & 2.99 & 1.87 & 1.34 & 1.25 & 1.10 \\
\hline Variance (\%) & 21.38 & 13.37 & 9.60 & 8.94 & 7.86 \\
\hline Cumulative variance $(\%)$ & 21.38 & 34.75 & 44.36 & 53.30 & 61.17 \\
\hline
\end{tabular}

Table 7 . The factorial analysis data by varimax rotation at the $20-40 \mathrm{~cm}$ depth.

\begin{tabular}{cccccc}
\hline Factor & Factor1 & Factor2 & Factor3 & Factor4 & Factor5 \\
\hline${ }^{39} \mathrm{~K}$ & 0.08 & -0.56 & 0.39 & 0.39 & -0.17 \\
$\mathrm{U}$ & $\mathbf{0 . 8 7}$ & -0.12 & 0.10 & 0.10 & -0.04 \\
$\mathrm{Th}$ & $\mathbf{0 . 8 9}$ & 0.03 & -0.04 & 0.09 & 0.08 \\
$\mathrm{Clay}$ & 0.01 & 0.04 & 0.03 & $\mathbf{- 0 . 7 5}$ & -0.20 \\
$\mathrm{pH}$ & -0.06 & -0.07 & 0.02 & 0.01 & $\mathbf{0 . 6 8}$ \\
$\mathrm{P}$ & -0.01 & 0.41 & 0.01 & -0.25 & 0.50 \\
${ }^{40} \mathrm{~K}$ & -0.05 & $\mathbf{- 0 . 7 2}$ & -0.11 & -0.09 & 0.28 \\
Organic matter & 0.38 & 0.12 & -0.21 & 0.50 & 0.00 \\
$\mathrm{Ca}$ & -0.21 & -0.11 & 0.04 & -0.49 & 0.08 \\
$\mathrm{Mg}$ & -0.06 & 0.26 & 0.74 & 0.19 & -0.24 \\
$\mathrm{Cu}$ & 0.18 & 0.07 & -0.02 & 0.17 & 0.48 \\
$\mathrm{Zn}$ & -0.10 & 0.58 & 0.26 & 0.03 & 0.32 \\
$\mathrm{Fe}$ & 0.41 & -0.11 & 0.42 & -0.02 & 0.25 \\
$\mathrm{Mn}$ & 0.04 & -0.02 & $\mathbf{0 . 6 4}$ & -0.40 & 0.32 \\
Eigenvalue & 2.05 & 1.74 & 1.40 & 1.03 & 1.23 \\
Variance (\%) & 14.70 & 12.44 & 10.02 & 9.50 & 8.78 \\
Cumulative variance (\%) & 14.70 & 27.14 & 37.16 & 46.66 & 55.44 \\
\hline
\end{tabular}




\section{GEOAMBIENTE ON-LINE \\ Revista Eletrônica do Curso de Geografia do Campus Jataí - UP \\ www.jatai.ufg.br/geografia \\ | Jataí-GO | N.11 | jul-dez/2008 | ISSN 1679-9860}

For the variables analyzed at the $0-20 \mathrm{~cm}$ depth, 5 Factors were obtained that are responsible for more than $61 \%$ of the total variability. The recommended number of factors is that for which the auto values are more than 1 (KAISER, 1958). Factor 1, which explains $21 \%$ of the total variability, combines $U$, Th and clay as correlated variables. The correlation is possibly due to the fact that sugar cane has been cultivated in the area for more than five years and massive quantities of NPK, as well as gypsum, have been applied mainly at the $0-20 \mathrm{~cm}$ depth. The radionuclide concentrations that come with the fertilizer and gypsum formulas can be seen in Table 8. Gypsum (calcium sulfate dihydrate), an industrial by-product derived from phosphoric acid, contains calcium, sulfur, free water, besides $U$ and $T h$ in varied concentrations. It is used in agriculture in order to supply calcium and sulfur to the deeper soil horizons, helping plants to develop a root system that explore greater volumes of soil in the search for water and nutrients (NUERNBERG et al., 2002). Factor 2 holds 13\% of the total variability, being Fe and Mn the correlated variables. Factor 3, with $9 \%$ of the variability, combines $\mathrm{K}_{2} \mathrm{O}$ and organic matter as correlated variables. Factor 4, with $9 \%$ of the variability, shows the association of the variables $\mathrm{P}_{2} \mathrm{O}_{5}$ and $\mathrm{Cu}$, and Factor 5 , with $7 \%$ of the variability, has $\mathrm{pH}$ as the main variable, whose values are close to the neutral for both depths (Table 1). Calcium and magnesium contents added to the soil via the application of dolomitic sandstone increase the saturation of the bases.

Table 8. Statistics of the $\mathrm{K}$, eU and eTh radionuclide concentrations $\left(\mathrm{Bq} \mathrm{Kq}^{-1}\right)$ in fertilizer and gypsum samples $(n=20)$.

\section{NPK Formulas}
$0-18-20$
$0-25-25$
$18-07-28$
g y p s u m

\begin{tabular}{|c|c|c|c|c|c|c|c|c|c|c|c|c|}
\hline & $\mathrm{K}$ & $\mathrm{eU}$ & eTh & K & $\mathrm{eU}$ & eTh & K & $\mathrm{eU}$ & eTh & K & $\mathrm{eU}$ & eTh \\
\hline Minimum & 93 & 414,5 & 584,1 & 6448 & 22,1 & 145,3 & 8184 & 19,7 & 49,3 & 31 & 527,7 & 177,5 \\
\hline Maximum & 1116 & 926,2 & 1062 & 9207 & 60,3 & 167,7 & 9579 & 35,7 & 64,7 & 155 & 738 & 238,1 \\
\hline Mean & 603,5 & 684,4 & 788,5 & 7713 & 45,4 & 158,8 & 8855 & 27,3 & 58 & 82,6 & 641,5 & 201,7 \\
\hline Median & 589 & 663 & 758,2 & 7781 & 49,2 & 157,5 & 8866 & 28,3 & 57,4 & 93 & 632,2 & 195,8 \\
\hline $\mathrm{Sd}$. & 322,5 & 150,7 & 123,3 & 838,8 & 11,5 & 6,8 & 438,3 & 5,7 & 4,7 & 38,3 & 59,6 & 4,73 \\
\hline Vc. & 0,53 & 0,22 & 0,15 & 0,12 & 0,25 & 0,04 & 0,05 & 0,2 & 0.08 & 0,46 & 0,09 & 19,3 \\
\hline
\end{tabular}




\begin{tabular}{|c|c|c|c|c|c|c|c|c|c|c|c|c|}
\hline \multicolumn{8}{|c|}{$\begin{array}{r}\text { GEOAMBIENTE ON-LINE } \\
\text { Revista Eletrônica do Curso de Geografia do Campus Jataí - UF } \\
\text { www.jatai.ufg.br/geografia } \\
\text { | Jataí-Go | N.11 | jul-dez/2008 }\end{array}$} & \multicolumn{4}{|c|}{$\begin{array}{l}\text { PLEO } \\
\text { ISSN } 1679-9860 \\
\text { ISAMBIENTE } \\
\end{array}$} & \multirow[b]{2}{*}{0,61} \\
\hline Skewness * & 0,10 & $-0,06$ & 0,73 & $-0,9$ & $-0,9$ & $-0,2$ & 0,10 & 0,13 & -0.03 & 0,21 & 0,04 & \\
\hline Kurtosis * & $-1,15$ & $-0,62$ & 0,64 & $-0,9$ & 0,2 & $-0,8$ & $-0,9$ & $-1,5$ & $-0,96$ & $-0,8$ & $-0,6$ & $-0,83$ \\
\hline
\end{tabular}

* Dimensionless values; Sd. (standart deviation); Vc. $=$ (variation coefficient)

The 5 Factors at $20-40 \mathrm{~cm}$ depths are responsible for more than $55 \%$ of the total variability (Table 8). Factor 1 combines $U$ and $T h$ as correlated variables, analogous to the $0-$ $20 \mathrm{~cm}$ depth, that is, the origin of the radionuclide is the fertilizers and gypsum formulas added to the soil. The same applies to Factor 2, being $\mathrm{K}_{2} \mathrm{O}$ the main variable resulting from fertilization of the sugar cane area. Clay is the variable for Factor 4. Factor 5 has $\mathrm{pH}$ as the main variable, influenced by the addition of dolomitic limestone composed of $\mathrm{Ca}^{+2}$ and $\mathrm{Mg}^{+2}$.

\section{4 - Conclusions}

- The best correlations are between clay and uranium, and clay and thorium at the 0-20 cm depth.

- Varimax rotation yields for Factor 1 uranium, thorium and clay and for Factor 2, zinc and manganese as the main variables.

- Despite the high raionuclide contents found in different fertilizer and gypsum formulas, only small part or almost nothing is being retained by the soils. A small part of the fertilizers used in soil preparation for sugar cane plantation is actually being used, once a large part is lost by leaching, as consequence of low and laminar erosion.

\section{5 - References}

BARRETO, P.M.C.; AUSTERLITZ, C.; MALHEIROS, T. et al. Radioactive concrete sources at IRD/CNEN, Brazil, for the calibration of uranium exploration and environmental field instruments. Relatório IRD/DEX-3/CNEN, 66. 1986.

BOYLE, R.U. Geochemical prospecting for thorium and uranium deposits. Developments in economic geology, n.16, p. 71-78. 1982.

CLEMENTE, A. Pesquisa de variáveis múltiplas. Scientia et Labor, 1990. 204 p.

DICKSON, B.L. \& SCOTT, K. M. Interpretation of aerial gamma-ray surveys - adding the geochemical factors. AGSO Journal of Australian Geology \& Geophysics, Austrália, v.17, n.2, p.187-200. 1997. 
EL-ARABI, A.M. \& KHALIFA, I.H. Application of multivariate statistical analyses in the interpretation of geochemical behaviour of uranium in phosphatic rocks in the Red Sea, Nile Valley and Western Desert, Egypt. Journal of Environmental Radioactivity, 61, 169-190. 2002.

EMBRAPA. Levantamento de reconhecimento dos solos do estado do Paraná. Londrina. Iapar/Sudesul. V.2. (Boletim técnico n. 57). 1984.

FERNANDES, L.A. \& COIMBRA, A.M. O Grupo Caiuá $(K s)$ : revisão estratigráfica e contexto deposicional. Revista Brasileira de Geociências 24(4):164-176. 1994.

FERNANDES, L.A. \& COIMBRA, A.M. Revisão estratigráfica da parte oriental da bacia Bauru (Neocretáceo). Revista Brasileira de Geociências 30(4):723-734. 2000.

GIMENEZ, FILHO A. \& PIRES NETO, A. G., RICCOMINI, C. Mapeamento geológico do bloco SF-22-T (ACS-73). São Paulo; Instituto de Pesquisas Tecnológicas, 69 p. (relatório n. 14845). 1981.

JOHNSON, R.A. \& WICHERN, D.W. Applied multivariate statistical analysis. Englewood Clifs: Prentice-Hala, 607 p. 1990.

IAPAR. Cartas climáticas básicas do Estado do Paraná. Londrina, 41 p. 1978.

KAISER, H.F. The varimax criteria for analytical rotation in factor analysis. Psychometrika 23, 186-200. 1958.

KUMRU, M.N. \& BAKAÇ. M. R-mode factor analysis applied to the distribution of elements in soils from the Aydin basin, Turkey. Journal of Geochemical Exploration, 77, 81-91. 2003.

MARQUES, L.S. Rare elements. In: Piccirillo, E.M.; Melfi, A. J. The Mesozoic flood Volcanism of The Paraná Basin. São Paulo: Universidade de São Paulo, Instituto Astronômico e Geosfísico, p.499-504. 1988.

MEIJER, R.J.; JAMES, I.R.; JENNINGS, P.J. et al. Cluster analysis of radionuclide concentrations in beach sand. Applied Radiation and Isotopes, 54, 535-542. 2001.

MENDONZA, H.N.S.; LIMA, E.; ANJOS, L.H.C. et al. Propriedades químicas e biológicas de solo de tabuleiro cultivado com cana-de-açúcar com e sem queima da palhada. R. bras. Ci. Solo, 24:201-207. 2000.

NAVAS, A.; SOTO, J. \& MACHIN, J. ${ }^{238} U,{ }^{226} R a,{ }^{210} \mathrm{~Pb},{ }^{232} \mathrm{Th}$ and ${ }^{40} \mathrm{~K}$ activities in soil profiles of the Flysch sector (Central Spanish Pyrenees). Applied Radiation and Isotopes 57. 2002. 


\section{GEOAMBIENTE ON-LINE}

Revista Eletrônica do Curso de Geografia do Campus Jataí - UP www.jatai.ufg.br/geografia

| Jataí-GO | N.11 | jul-dez/2008

\section{МEO}

今̀MBIENTE

ISSN 1679-9860

NUERNBERG, N.J.; RECH, T.D. \& BASSO, C. Usos do gesso agrícola. Florianópolis: Epagri, 31p. Boletim Técnico, 122. 2002.

OLIVEIRA, J.J.; CHAVES, L.H.G.; QUEIROZ, J.E. et al. Variabilidade espacial de propriedades químicas em solo salino-sódico. R. Bras. Ci. Solo, 23:783-789. 1999.

PEREIRA, R.S. Sistema de tratamento de imagens multiespectrais digitais. Curitiba, 262p. (Doutorado - Universidade Federal do Paraná). 1995.

ROMESBURG, H.C. Cluster analysis for researchers. California, Lifetime Learning Publications, 334p. 1984.

SNEDECOR, G.W. \& COCHRAN, W.G. Statistical methods. 6.ed. Ames, Iowa State University Press, 593p. 1967.

TEDESCO, J. M.; GIANELLO, C.; BISSANI, C. A. et al. Análises de solo, plantas e outros materiais. Porto Alegre: Departamento de solos. UFRGS. 174p. 1995. 